\title{
Voltage-gated sodium channel expression and action potential generation in differentiated NG108-15 cells
}

\author{
Jinxu Liư ${ }^{1}$, Huiyin Tu${ }^{1}$, Dongze Zhang ${ }^{1}$, Hong Zheng ${ }^{2}$ and Yu-Long $\mathrm{Li}^{1,2^{*}}$
}

\begin{abstract}
Background: The generation of action potential is required for stimulus-evoked neurotransmitter release in most neurons. Although various voltage-gated ion channels are involved in action potential production, the initiation of the action potential is mainly mediated by voltage-gated $\mathrm{Na}^{+}$channels. In the present study, differentiation-induced changes of mRNA and protein expression of $\mathrm{Na}^{+}$channels, $\mathrm{Na}^{+}$currents, and cell membrane excitability were investigated in NG108-15 cells.
\end{abstract}

Results: Whole-cell patch-clamp results showed that differentiation (9 days) didn't change cell membrane excitability, compared to undifferentiated state. But differentiation (21 days) induced the action potential generation in $45.5 \%$ of NG108-15 cells (25/55 cells). In 9-day-differentiated cells, $\mathrm{Na}^{+}$currents were mildly increased, which was also found in 21-day differentiated cells without action potential. In 21-day differentiated cells with action potential, $\mathrm{Na}^{+}$currents were significantly enhanced. Western blot data showed that the expression of $\mathrm{Na}^{+}$channels was increased with differentiated-time dependent manner. Single-cell real-time PCR data demonstrated that the expression of $\mathrm{Na}^{+}$channel mRNA was increased by 21 days of differentiation in NG108-15 cells. More importantly, the mRNA level of $\mathrm{Na}^{+}$channels in cells with action potential was higher than that in cells without action potential.

Conclusion: Differentiation induces expression of voltage-gated $\mathrm{Na}^{+}$channels and action potential generation in NG108-15 cells. A high level of the $\mathrm{Na}^{+}$channel density is required for differentiation-triggered action potential generation.

Keywords: Action potential, $\mathrm{Na}^{+}$channel, NG108-15 cell, Patch clamp, Single-cell real-time PCR, Western blot

\section{Background}

Exploring cell molecular and electrophysiological properties such as expression and current of ion channels, and action potentials is very important for understanding the physiological and pathophysiological functions of the excitable cells including neurons, muscle cells, and endocrine cells. Although acute-isolated primary cell is the optimum choice for pursuing these measurements, cell lines are also served as an appropriate tool for the cell molecular and electrophysiological studies, because cell lines provide the advantage of enough

\footnotetext{
*Correspondence: yulongli@unmc.edu

'Department of Emergency Medicine, University of Nebraska Medical Center, Omaha, NE 68198, USA

${ }^{2}$ Department of Cellular \& Integrative Physiology, University of Nebraska Medical Center, Omaha, NE 68198, USA
}

homogeneous cells that can make the investigation under easily controlled conditions.

NG108-15 cell line is a hybrid cell line formed by the fusion of mouse N18TG2 neuroblastoma cells and rat C6BU-1 glioma cells [1]. After differentiation, this cell line presents neurite extension, forms synapses, and develops the ultimate neural property of acetylcholine release and specific activities of choline acetyltransferase and acetylcholinesterase [2-4]. Therefore, many studies used NG108-15 cells as the cholinergic cells to investigating electrophysiological kinetics and cell functions of neurons [4-12].

Action potential is an important physiological feature of the excitable cells. In most vertebrate neurons, action potential production is required for neuronal excitation and stimulus-evoked neurotransmitter release, which are involved in neuron-to-neuron communication [13,14]. Although action potentials are generated by voltage-gated 
$\mathrm{Na}^{+}, \mathrm{K}^{+}$, and $\mathrm{Ca}^{++}$channels existed in the cell membrane, the influx of $\mathrm{Na}^{+}$ions through voltage-gated $\mathrm{Na}^{+}$channels plays the most important role in the initiation and propagation of action potential $[15,16]$. In order to clarify the relationship between action potential generation and sodium channel density, in this study, we investigated the time-course for differentiation-induced changes of membrane excitability and $\mathrm{Na}^{+}$channels in NG108-15 cells.

\section{Results}

\section{Differentiated NG108-15 cells bear cholinergic neuronal}

\section{property}

As a cholinergic neuron marker, choline acetyltransferase (ChAT) was detected in NG108-15 cells by immunofluorescence staining. In the undifferentiated cells, there were a few ChAT-positive cells and very low-level ChAT images in the ChAT-positive cells (Figure 1). After 21 days of differentiation, all cells were ChAT positive and presented high-level ChAT images (Figure 1).

Differentiation-induced action potential in NG108-15 cells Using whole-cell current-clamp recording method, the response of cell membrane to current injections was measured in undifferentiated and differentiated NG10815 cells (Figure 2 and Table 1). In undifferentiated cells (day0), the resting membrane potential (RMP) was -34.9 $\pm 1.4 \mathrm{mV} \quad(\mathrm{n}=22)$, and current injection (100 pA) induced a small depolarization. However, the action potential didn't appear in undifferentiated cells.

After 9 days of differentiation, the RMP was increased to $-43.2 \pm 1.5 \mathrm{mV}(\mathrm{n}=15 ; \mathrm{P}<0.05$ vs. Day 0$)$, and the depolarization amplitude was increased to $45 \pm 2.9 \mathrm{mV}$ $(\mathrm{P}<0.05$ vs. Day 0$)$, compared with those in undifferentiated state. However, current injection (100 pA) didn't yet induce the action potential in the cells with 9 days of differentiation.

After 21 days of differentiation, 45.5\% of cells (25/55) had the ability to generate the action potential upon the current injection (100 pA), and the average frequency of action potentials was $6.7 \pm 1.1$ spikes/s (Figure 2). $\mathrm{A} \mathrm{Na}^{+}$ channel antagonist tetrodotoxin (TTX, $1 \mu \mathrm{M})$ could totally block the generation of action potential, indicating that differentiation-induced action potential is $\mathrm{Na}^{+}$channel dependent. The current threshold-inducing action potential was $48.2 \pm 2.7 \mathrm{pA}$ in the cells with action potential. We also found that the cells with action potential had a more negative RMP of $-56.1 \pm 1.6 \mathrm{mV}$, compared to day 0 , day 9 , and day 21 without action potential cells (Table 1$)$. On the contrary, the other cells (54.5\%, 30/55) didn't generate the action potential after 21 days of differentiation. The cells without action potential presented similar electrical characteristics to those cells with 9 days of differentiation (Table 1).

Additionally, we also measured the generation of the action potential after 35 days of differentiation. After 35 days of differentiation, there was no significant difference on the ratio of cells with/without action potential (data not shown), compared with that after 21 days of differentiation.

\section{Changes of $\mathrm{Na}^{+}$currents induced by differentiation}

After the recording of the action potential, $\mathrm{Na}^{+}$currents were recorded under voltage-clamp mode. Using this

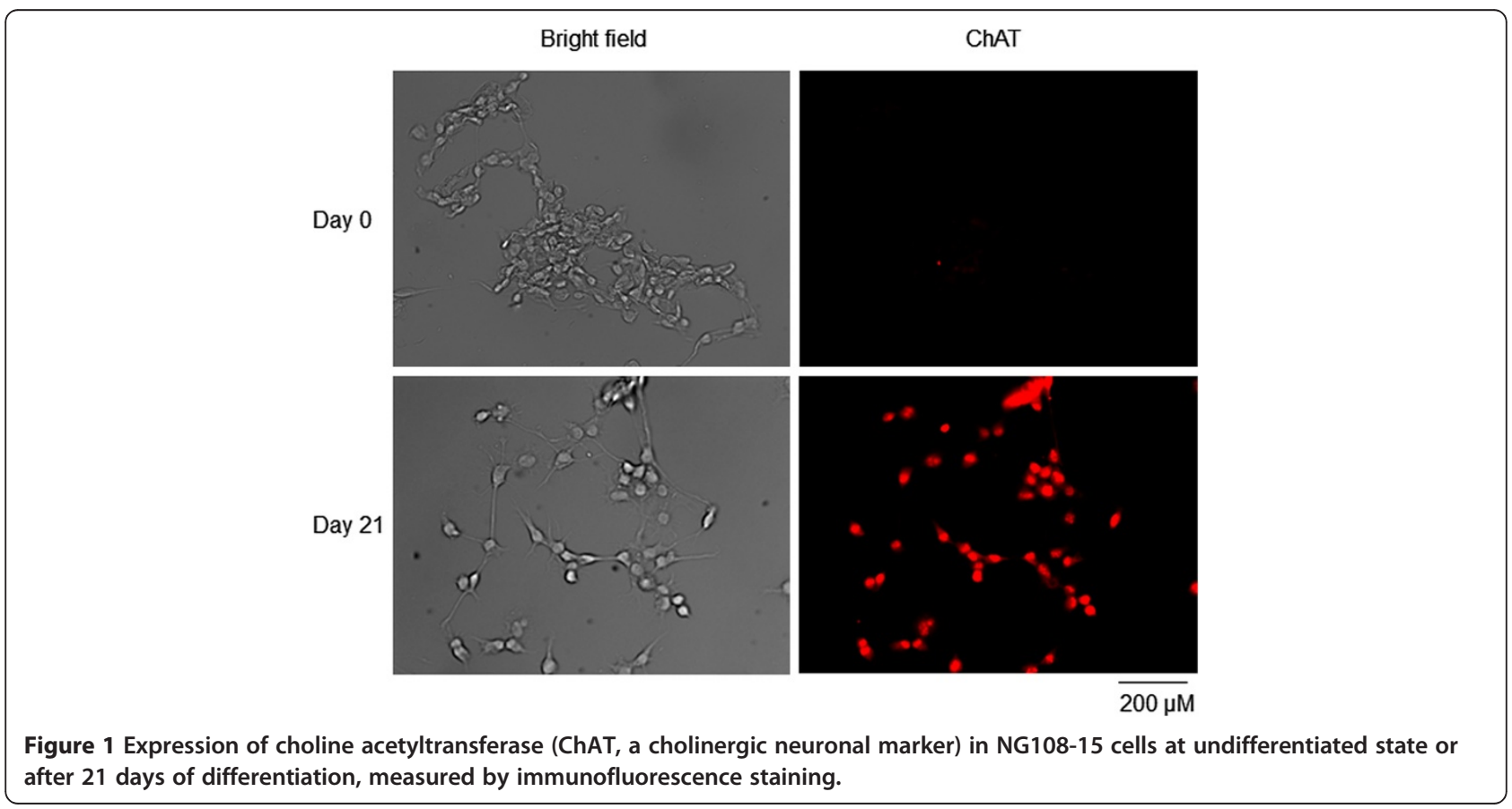




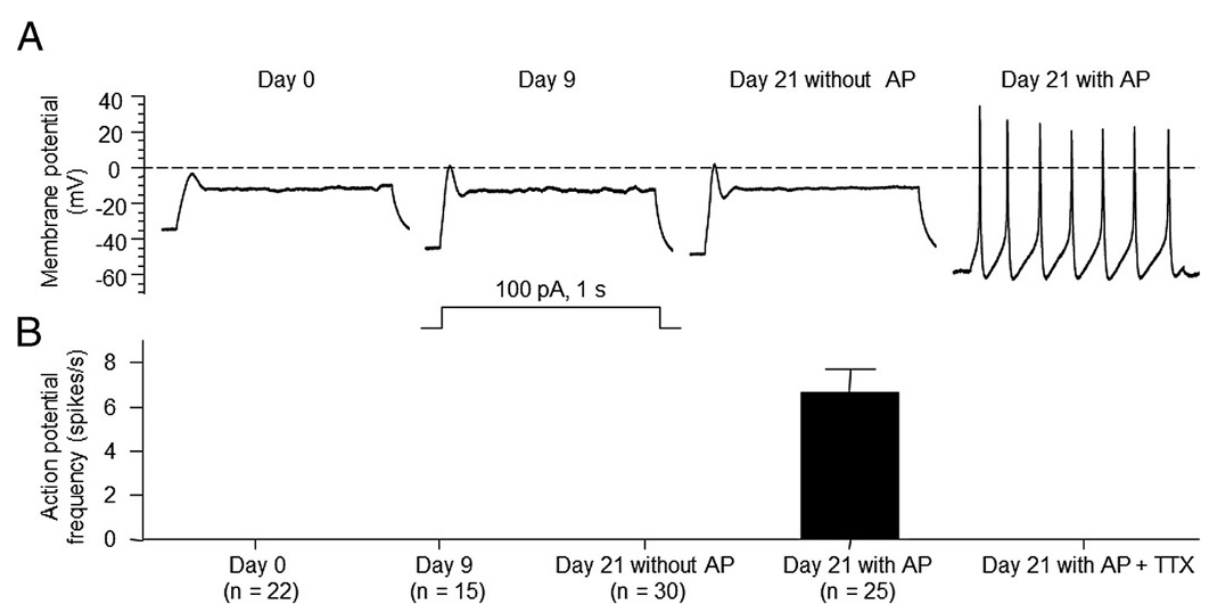

Figure 2 Alterations in membrane excitability of NG108-15 cells induced by differentiation. A: Representative traces show the membrane potential response to a depolarizing current injection (100 pA, $1 \mathrm{sec}$ ) under whole-cell current-clamp configuration. B: Action potential (AP) frequency in undifferentiated (day0) and differentiated NG108-15 cells. TTX: tetrodotoxin. Data are means \pm SEM, $\mathrm{n}$ is the number of cells.

method, the $\mathrm{Na}^{+}$currents and action potential were recorded in the same cell. In the undifferentiated cells, the $\mathrm{Na}^{+}$current density was $-29.2 \pm 3 \mathrm{pA} / \mathrm{pF}(\mathrm{n}=10)$. After 9 days of differentiation, the $\mathrm{Na}^{+}$current density of NG108-15 cells increased to $-40.8 \pm 3.3 \mathrm{pA} / \mathrm{pF}$ $(\mathrm{n}=10, \mathrm{p}>0.05$ vs. undifferentiated cells). After 21 days of differentiation, the $\mathrm{Na}^{+}$current density was not significantly altered in the cells without action potential $(-44.8 \pm 4.7 \mathrm{pA} / \mathrm{pF} ; \mathrm{n}=10)$, compared to that in the cells with 9 days of differentiation. However, the $\mathrm{Na}^{+}$current density was significantly increased in the cells with action potential $(-113.5 \pm 12.4 \mathrm{pA} / \mathrm{pF}, \mathrm{n}=10 ; \mathrm{p}<0.05$ vs. day 0 , day 9 , and day 21 without action potential cells; Figure 3). The $\mathrm{Na}^{+}$current density detected in undifferentiated and differentiated cells was completely inhibited by $1 \mu \mathrm{M}$ TTX (data not shown), suggesting that only TTX-sensitive $\mathrm{Na}^{+}$channels exist in NG108-15 cells.

\section{Expression of $\mathrm{Na}^{+}$channel protein induced by differentiation}

It has been reported that only $\mathrm{Na}_{\mathrm{v}} 1.7$ (a primary TTXsensitive $\mathrm{Na}^{+}$channels) expression is increased after
NG108-15 cell differentiation [9]. Therefore, we used western blot analysis to measure the expression of $\mathrm{Na}_{\mathrm{v}} 1.7$ protein in undifferentiated and differentiated NG108-15 cells. As shown in Figure 4, the protein level of $\mathrm{Na}_{\mathrm{v}} 1.7$ increased after 9 days of differentiation and further enhanced after 21 days of differentiation. We couldn't compare the expression of $\mathrm{Na}_{\mathrm{v}} 1.7$ protein between the cells with and without action potential due to technical limitation.

\section{Expression of $\mathrm{Na}_{\mathrm{v}} 1.7$ mRNA induced by differentiation}

Using single-cell real-time PCR, we measured the $\mathrm{Na}_{\mathrm{v}} 1.7$ mRNA in undifferentiated and differentiated NG108-15 cells. After 21 days of differentiation, expression of $\mathrm{Na}_{\mathrm{v}} 1.7$ mRNA significantly increased in NG108-15 cells. More importantly, the level of $\mathrm{Na}_{\mathrm{v}} 1.7$ mRNA in the cells with action potential was higher than that in the cells without action potential (Figure 5).

\section{Relationships among $\mathrm{Na}_{\mathrm{v}} 1.7$ mRNA, $\mathrm{Na}^{+}$current density, and action potential frequency}

Using linear regression analysis, we found that there were correlations among $\mathrm{Na}_{\mathrm{v}} 1.7$ mRNA, $\mathrm{Na}^{+}$current

Table 1 Differentiation-induced changes in membrane properties of NG108-15 cells

\begin{tabular}{llllll}
\hline & $\mathbf{n}$ & $\begin{array}{l}\text { RMP } \\
(\mathbf{m v})\end{array}$ & $\begin{array}{l}\mathbf{V}_{\text {max }} \\
(\mathbf{m V} / \mathbf{m s})\end{array}$ & $\begin{array}{l}\text { Depolarization amplitude } \\
(\mathbf{m V})\end{array}$ & $\begin{array}{l}\text { Current threshold } \\
(\mathbf{p A})\end{array}$ \\
\hline Day 0 & 22 & $-34.9 \pm 1.4$ & $20.1 \pm 0.9$ & $32.1 \pm 1.6$ & $\mathrm{n} / \mathrm{a}$ \\
$\begin{array}{llll}\text { Day 9 } \\
\text { Day 21 }\end{array}$ & 15 & $-43.2 \pm 1.5^{*}$ & $23.2 \pm 1.2$ & $45.0 \pm 2.9^{*}$ & $\mathrm{n} / \mathrm{a}$ \\
$\begin{array}{l}\text { Without AP } \\
\text { Day 21 }\end{array}$ & 30 & $-45.4 \pm 2.1^{*}$ & $28.5 \pm 3.5^{*}$ & $46.1 \pm 4.7^{*}$ & $\mathrm{n} / \mathrm{a}$ \\
with AP & & & & \\
\hline
\end{tabular}

RMP resting membrane potential; $V_{\max }$ maximum rate of depolarization of action potential (AP). Data are means $\pm S E M, n$ is the number of cells studied. ${ }^{*} \mathrm{P}<0.05$ vs. 0 day of differentiation (day 0 , undifferentiated cells); ${ }^{\sharp} \mathrm{P}<0.05$ vs. cells after 9 days of differentiation (day 9 ); ${ }^{5} \mathrm{P}<0.05$ vs. cells after 21 days of differentiation (day 21) without AP. 


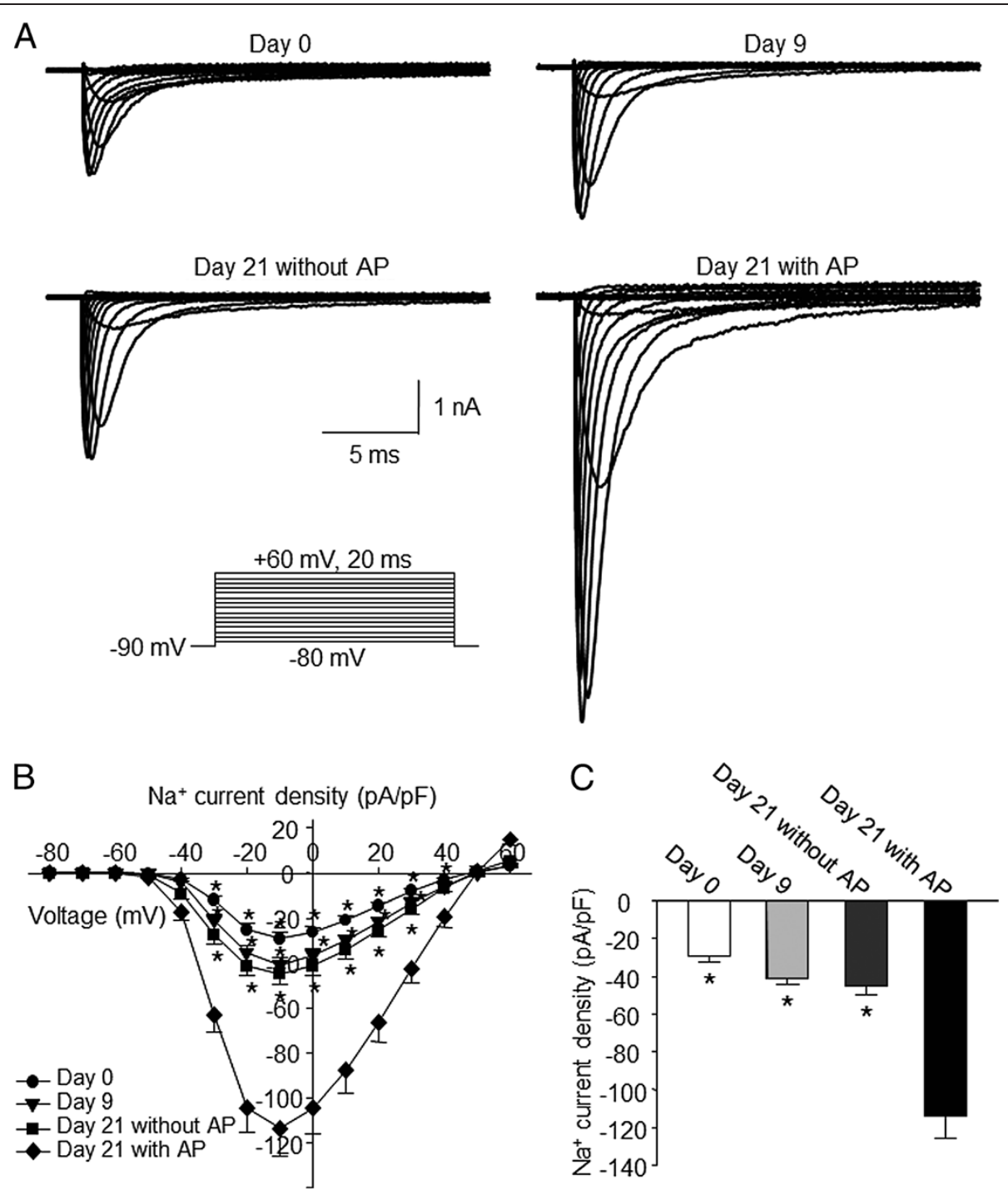

Figure 3 Original recording (A), current-voltage (I-V) curve (B), and mean data (C) of the voltage-gated $\mathrm{Na}^{+}$currents in undifferentiated and differentiated NG108-15 cells, measured by whole-cell voltage-clamp technique. Data are means \pm SEM, $n=10$ cells in each group. ${ }^{*} P<0.05$ vs. cells after 21 days of differentiation with action potential (AP).

density, and action potential frequency (Figure 6). Additionally, we also determined that $77 \mathrm{pA} / \mathrm{pF}\left(\mathrm{Na}^{+}\right.$current density) was required to induce the generation of an action potential in NG108-15 cells.

\section{Discussion}

Previous studies have found that during the differentiation of NG108-15 cells, dibutyryl cyclic AMP is a key factor in the culture medium, which can stimulate NG108-15 cells to present a morphological alterations (such as the increase in cell diameter, neurite length, and number of clear vesicles) and to develop the cholinergic neuronal properties including stimulus-dependent acetylcholine release and activities of ChAT and acetylcholinesterase [2-4]. Our present study demonstrated that
ChAT, a cholinergic neuron marker, was expressed in all differentiated NG108-15 cells (Figure 1). Based on these results, NG108-15 cell line is considered to be a suitable cell line for studying cholinergic neuronal function.

Although many studies focused on the measurement of ion channels (such as voltage-gated $\mathrm{Na}^{+}, \mathrm{Ca}^{++}$, and $\mathrm{K}^{+}$ channels) in NG108-15 cells [5-10,17-20], a few studies recorded the action potential and obtained inconsistent results [21-23]. In Kowtha's study, the differentiated-cell excitability is still lower under a very high currentstimulation $(30 \mathrm{nA})$ [22]. Extracellularly added $\mathrm{NH}_{4} \mathrm{Cl}$ increased the cell excitability via an elevation in intracellular $\mathrm{pH}$ [22]. Doebler reported that a high currentstimulation (700 pA, $75 \mathrm{~ms})$ induced the generation of action potential after NG108-15 cells were differentiated 


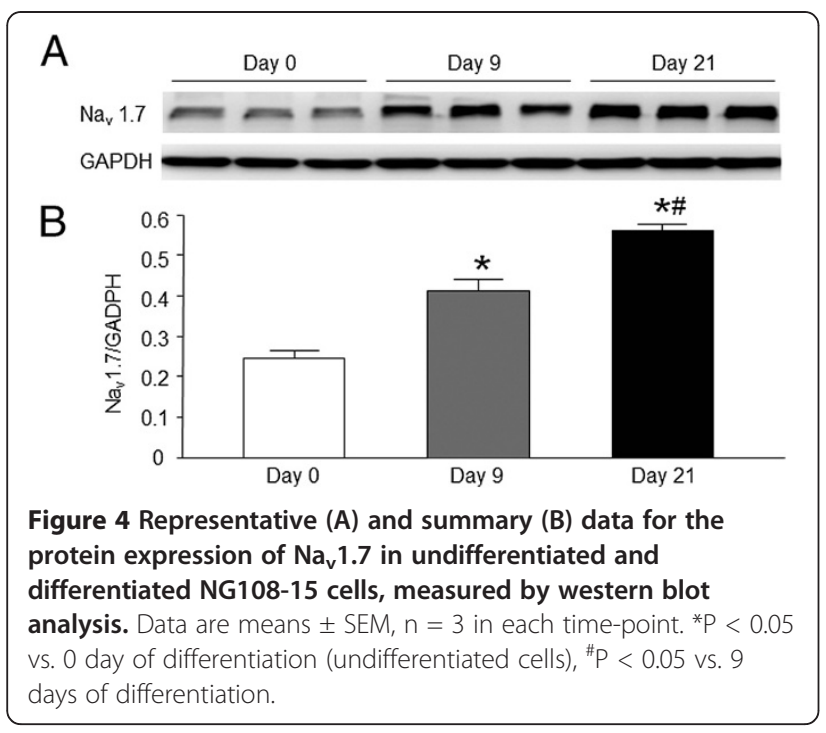

over 5 days [21]. Usually, action potential recording needs to be kept a long time for measuring the cell excitability (including action potential frequency and current threshold-inducing action potential) and investigating the effect of drugs. However, the high current-stimulation can induce the cell damage and shorten the cell recording time. Additionally, a current stimulation less than $300 \mathrm{pA}$ is normally used for action potential recording in isolated primary neuron cells. In present study, therefore, we chose a low current stimulation (100 pA) to investigate the time course for differentiation-induced alteration of cell excitability in NG108-15 cells. We observed that short-time differentiation ( 9 days) didn't change the cell excitability, compared with undifferentiated condition (Figure 2). Moreover, only about a half of cells generated action potentials after 3 week differentiation (Figure 2). A similar result was found in Ma's study [23]. This research group considered there are two types of the cells after long-time differentiation: type 1 neuron-like cells with neuronal morphologies and excitable membrane properties, and type 2 cells with a proliferative property [23].

It is well known that $\mathrm{Na}^{+}$currents mainly mediate the upstroke of action potential $[15,24]$. However, it is unclear how much functional $\mathrm{Na}^{+}$channel and $\mathrm{Na}^{+}$current density are required for the generation of neuronal action potential in NG108-15 cells. We recorded the action potential and voltage-gated $\mathrm{Na}^{+}$currents in the
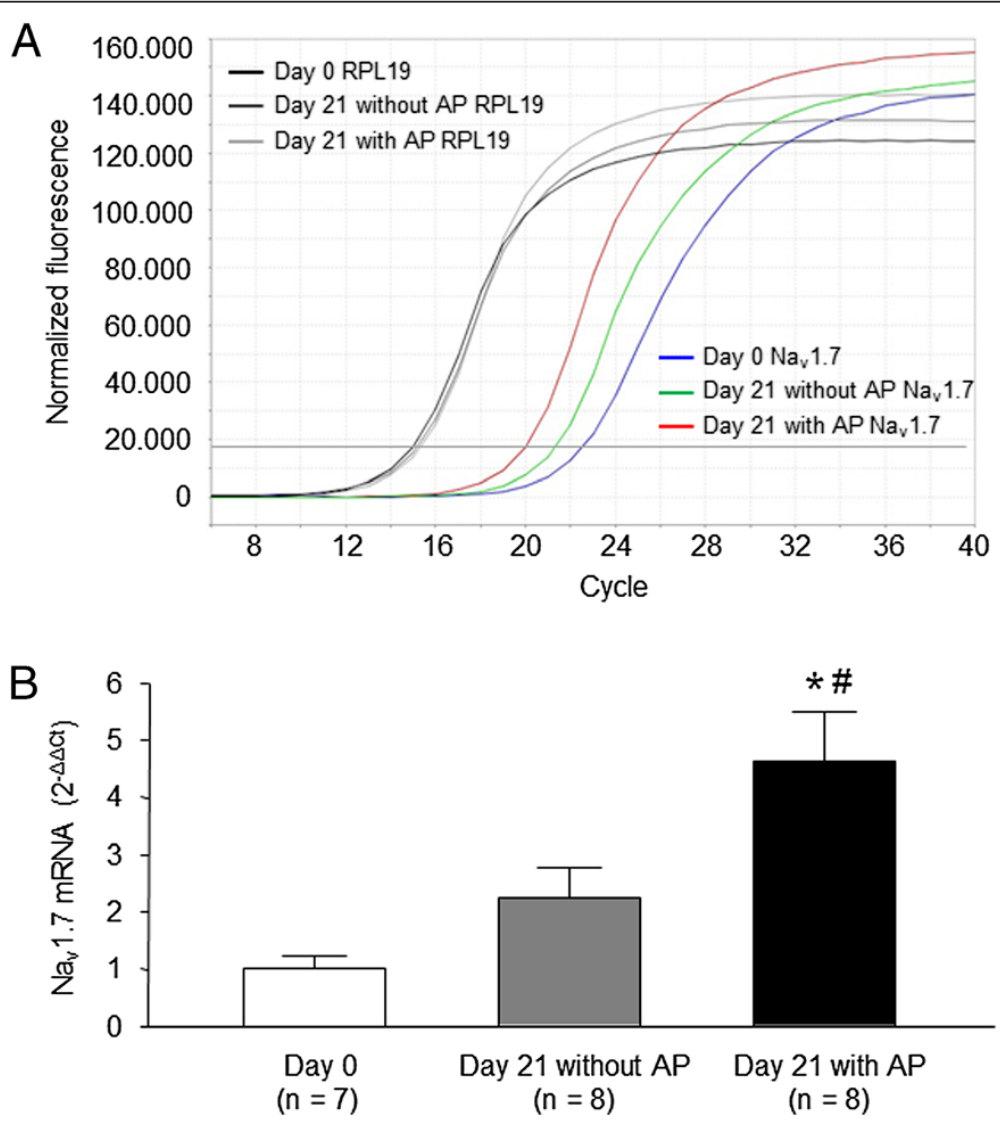

Figure 5 Representative (A) and summary (B) data for the mRNA expression of $\mathrm{Na}_{\mathrm{v}} 1.7$ in undifferentiated and differentiated NG108-15 cells; quantified by single-cell real-time PCR, RPL19 (a housekeeping gene) was used as the internal control. Data are means \pm SEM, $n$ is the number of cells. ${ }^{*} \mathrm{P}<0.05$ vs. 0 day of differentiation (undifferentiated cells), ${ }^{\#} \mathrm{P}<0.05$ vs. cells after 21 days of differentiation without AP. 


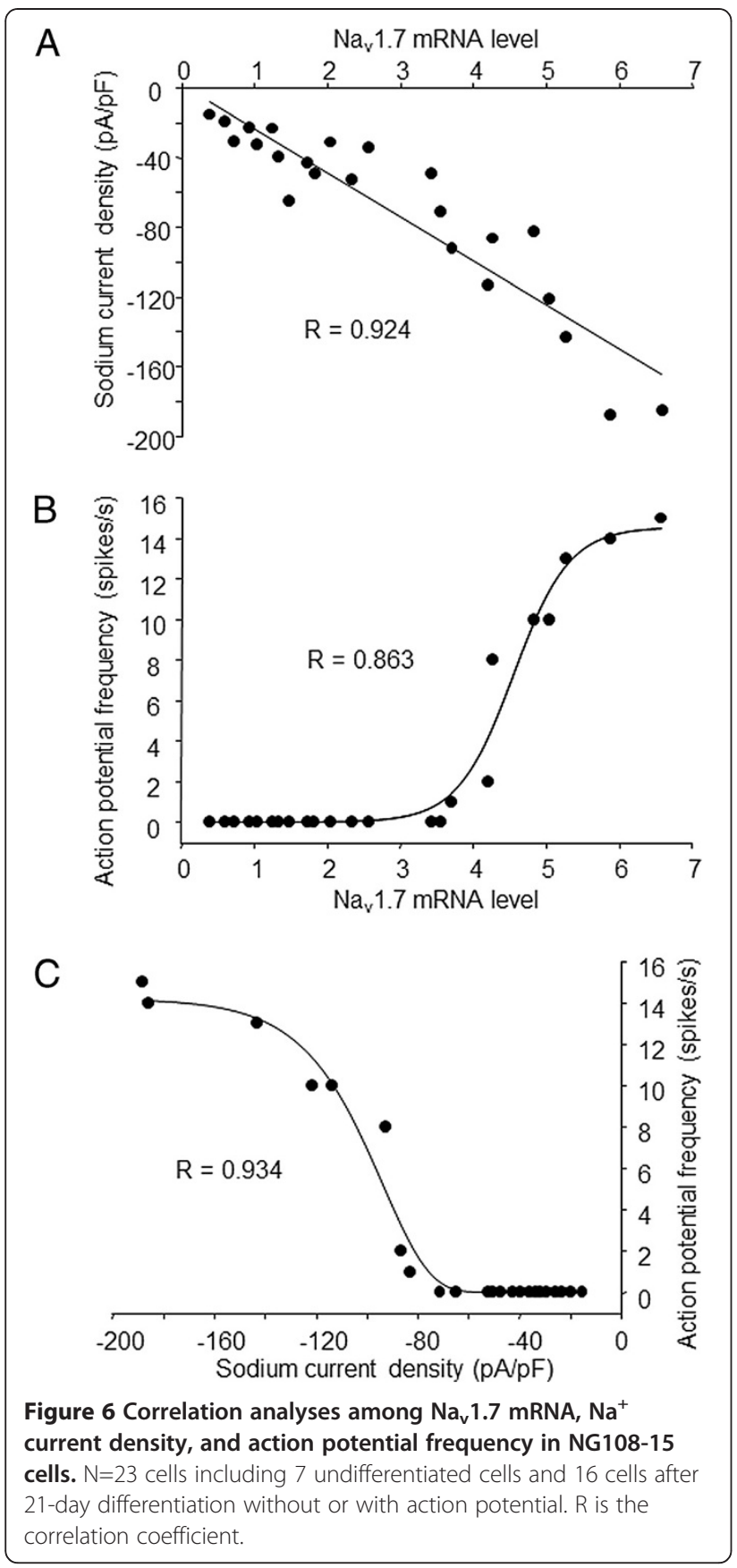

same cell. Using this technique, we found that differentiation-induced mild increase of $\mathrm{Na}^{+}$currents didn't trigger the generation of action potential (such as day 9 and day 21 without AP groups, Figure 3), and a significant increase of $\mathrm{Na}^{+}$currents is needed for generating action potentials in differentiated NG108-15 cells (such as day 21 with AP group, Figure 3). The data from linear regression analysis (Figure 6) suggest that differentiationenhanced $\mathrm{Na}^{+}$current density should reach a high level $(77 \mathrm{pA} / \mathrm{pF})$ close to the current threshold for generating action potentials in NG108-15 cells, which is also supported by western blot and single-cell real-time PCR data (Figures 4 and 5). Similarly, a previous study has demonstrated that action potential generation requires a high $\mathrm{Na}^{+}$channel density in the axon initial segment of cortical layer 5 pyramidal neurons [24].

There is no direct evidence showing the involvement of $\mathrm{Na}_{\mathrm{v}}$ channels in acetylcholine release from cholinergic neurons. However, many studies have shown that $\mathrm{Ca}^{++}$ influx through the voltage-gated $\mathrm{Ca}^{++}$channels is a key trigger for the release of neurotransmitters including acetylcholine [25-31]. Voltage-gated $\mathrm{Ca}^{++}$channels are activated and intracellular $\mathrm{Ca}^{++}$level is increased when the cell membrane is depolarized by an action potential [32-34]. Therefore, $\mathrm{Na}^{+}$channel-initiated action potential might link to the acetylcholine release through triggering $\mathrm{Ca}^{++}$influx.

Our recent study has shown that differentiation also induces the alteration of voltage-gated $\mathrm{Ca}^{++}$channel mRNA, protein and current in NG108-15 cells [10]. Additionally, $0.1 \mathrm{mM} \mathrm{Cd}^{++}$(a common voltage-gated $\mathrm{Ca}^{++}$channel blocker) reduces the action potential frequency and increases the current threshold-inducing action potential in differentiated NG108-15 cells (data not shown). It is possible that enhanced expression of voltage-gated $\mathrm{Ca}^{++}$channels also contributes to action potential generation in NG108-15 cells.

In addition to fasting activating and inactivating $\mathrm{Na}^{+}$ current, the persistent $\mathrm{Na}^{+}$current, also known as noninactivating $\mathrm{Na}^{+}$current are recorded in many types of excitable neurons $[35,36]$. Wu, et al. reported that the non-inactivating $\mathrm{Na}^{+}$current was characterized in differentiated NG108-15 cells, and this type of $\mathrm{Na}^{+}$current might facilitate neuronal hyper-excitability [37]. However, the origin of the non-inactivating $\mathrm{Na}^{+}$current is unclear. Three hypotheses have been proposed: first, the noninactivating $\mathrm{Na}^{+}$current originates from the window current; second, the non-inactivating $\mathrm{Na}^{+}$current originates from the mutation in the inactivation properties of the same channels that generate the fasting activating and inactivating $\mathrm{Na}^{+}$currents; third, the non-inactivating $\mathrm{Na}^{+}$ current originates from a special subtype of $\mathrm{Na}^{+}$channels $[35,36]$. Based on these uncertainties, we did not address the correlation between non-inactivating $\mathrm{Na}^{+}$current and action potential in the present study.

Although established neuronal cell lines including NG108-15 cells may provide some valuable data, extrapolation to the original neuronal cells should be cautiously used because an endless debate for the neuronal cell lines is still presented in respect of genetic, differentiated, biochemical, and physiological aspects.

\section{Conclusion}

It is the first time to investigate the time course for differentiation-induced changes in cell excitability and 
voltage-gated $\mathrm{Na}^{+}$channels in NG108-15 cells using electrophysiological and molecular techniques. Differentiation time-dependently enhances the expression and current density of voltage-gated $\mathrm{Na}^{+}$channels and induces about a half of cells to generate action potential. These results suggest that action potential is generated in differentiated NG108-15 cells with a high voltagegated $\mathrm{Na}^{+}$channel density.

\section{Methods}

\section{Cell culture and differentiation}

The neuroblastoma $\times$ glioma NG108-15 cell line was obtained from the American Type Culture Collection (ATCC, Manassas, VA). NG108-15 cells were cultured as previously described [10]. Briefly, cells were cultured at a density of $1 \times 10^{4}$ cells $/ \mathrm{cm}^{2}$ on either a $60 \mathrm{~mm}$ plastic dish or a $35 \mathrm{~mm}$ plastic dish containing glass cover slips in Dulbecco's modified Eagle's medium (DMEM) with $10 \%$ fetal bovine serum. Differentiation was induced by culturing the cells in a serum-free medium consisting of DMEM, N2 supplements, $1 \mathrm{mM}$ dibutyryl cyclic AMP, and antibiotics. Cells were used for experiments after $0-21$ days of differentiation.

\section{Immunofluorescent staining}

NG108-15 cells plated onto coverslips were fixed with $4 \%$ paraformaldehyde for $10 \mathrm{~min}$ at $4^{\circ} \mathrm{C}$ and then blocked with $10 \%$ normal goat serum for $1 \mathrm{~h}$ at room temperature. The NG108-15 cells were incubated with primary antibody against choline acetyltransferase (ChAT; Novus Biologicals, Littleton, CO) overnight at $4^{\circ} \mathrm{C}$. Then, the NG108-15 cells were incubated with fluorescence-conjugated secondary antibody (Santa Cruz Biotechnology, Santa Cruz, CA) for $1 \mathrm{~h}$ at room temperature. Finally, the NG108-15 cells were observed under a Leica fluorescent microscope with corresponding filter. Pictures were captured by a digital camera system. No staining was seen when PBS was used instead of the primary antibody in the above procedure.

\section{Recording of action potentials and sodium currents}

Action potential and $\mathrm{Na}^{+}$currents were recorded by the whole-cell patch-clamp technique using Axonpatch 200B patch-clamp amplifier (Axon Instruments, Sunnyvale, $\mathrm{CA})$.

Action potential was recorded in the current-clamp mode. Resistance of the patch pipette was 1-2 M $\Omega$ when filled with (in $\mathrm{mM}$ ) $105 \mathrm{~K}$-aspartate, $20 \mathrm{KCl}, 1$ $\mathrm{CaCl}_{2}, 5 \mathrm{MgATP}, 10$ HEPES, 10 EGTA, and 25 glucose, $\mathrm{pH} 7.2$ with $\mathrm{KOH}$. RNase inhibitor was added to the pipette solution to prevent the degradation of mRNA. The extracellular solution consisted of (in $\mathrm{mM}$ ): 140 $\mathrm{NaCl}, 5.4 \mathrm{KCl}, 0.5 \mathrm{MgCl}_{2}$, $2.5 \mathrm{CaCl}_{2}$, $5.5 \mathrm{HEPES}, 11$ glucose, and 10 sucrose, $\mathrm{pH} 7.4$ with $\mathrm{NaOH}$. Action potential was elicited by a ramp current injection of 0 $300 \mathrm{pA}$ to measure the current threshold-inducing action potential. The clamp-current at generation of the first action potential is defined as the current thresholdinducing action potential. Frequency of action potentials was measured in a 1second current clamp (100 pA).

To record $\mathrm{Na}^{+}$currents after action potential recording in the same cell, the extracellular solution was changed to a solution consisting of (in mM): $70 \mathrm{NaCl}, 60$ choline- $\mathrm{Cl}, 10 \mathrm{CsCl}, 10 \mathrm{TEA}-\mathrm{Cl}, 2$ 4-AP, $0.1 \mathrm{CdCl}_{2}, 4$ $\mathrm{MgCl}_{2}, 10 \mathrm{HEPES}$, and 10 glucose, $\mathrm{pH} 7.4$ with $\mathrm{CsOH}$. Junction potential was calculated to be $+9.7 \mathrm{mV}$ using pClamp 10.2 software, and all values of membrane potential given throughout were corrected using this value. Series resistance of 5-10 M $\Omega$ was electronically compensated $80-90 \%$. Current traces were sampled at 10 $\mathrm{kHz}$ and filtered at $5 \mathrm{kHz}$. $\mathrm{Na}^{+}$currents were evoked from a holding potential of $-90 \mathrm{mV}$ by stepping to voltages between -80 and $+60 \mathrm{mV}$ in $10 \mathrm{mV}$ increment for $20 \mathrm{~ms} .1 \mu \mathrm{M}$ tetrodotoxin was used to block $\mathrm{Na}^{+}$currents. Peak currents were measured for each test potential and current density was calculated by dividing peak current by cell membrane capacitance. pClamp 10.2 program (Axon Instruments) was used for data acquisition and analysis. All experiments were done at room temperature. After the recording of $\mathrm{Na}^{+}$currents, the cell was also used for single-cell real-time RT-PCR experiments.

\section{Western blot}

Western blot was performed as described previously [38]. The protein of NG108-15 cell lysates was extracted with the lysing buffer (10 $\mathrm{mM}$ Tris, $1 \mathrm{mM}$ EDTA, $1 \%$ SDS, pH 7.4) plus protease inhibitor cocktail (SigmaAldrich, $100 \mu \mathrm{l} / \mathrm{ml}$ ). Total protein concentration was determined using a bicinchoninic acid protein assay kit (Pierce, Rockford, IL). Equal amounts of the protein samples were loaded and then separated on a $10 \%$ sodium dodecyl sulfate (SDS)-polyacrylamide gel. The proteins of these samples were electrophoretically transferred to PVDF membrane. The membrane was probed with mouse anti- $\mathrm{Na}_{\mathrm{v}} 1.7$ antibody (NeuroMab, Davis, CA) and a peroxidase-conjugated goat anti-mouse secondary antibody (Pierce). The signal was detected using enhanced chemiluminescence substrate (Pierce) and the bands were analyzed using UVP bioimaging system. The membrane was reprobed with mouse antiGAPDH antibody (Santa Cruz Biotechnology, Santa Cruz, CA) and normalizing target protein intensity to that of GAPDH.

\section{Single-cell real-time RT-PCR}

Single-cell real-time RT-PCR was performed as described previously $[10,39]$. After the recording of $\mathrm{Na}^{+}$ 
currents, the cellular content was obtained by applying suction on patch pipette and expelled into a 0.2-ml PCR tube containing following reagents: $5 \mu \mathrm{l}$ volume consisting of $1 \mu \mathrm{l} 5 \mathrm{X}$ lysis buffer $(100 \mu \mathrm{l} 5 \mathrm{X}$ lysis buffer consisting of $20 \mu \mathrm{l} 5 \mathrm{X} \mathrm{M}$-MLV reverse transcriptase buffer (Invitrogen, Carlsbad, CA), $5 \mu$ l Nonidet P-40, $75 \mu \mathrm{l}$ RNase-free water), $0.5 \mu \mathrm{l}$ RNA guard Mix (100 $\mu \mathrm{l}$ consisting of $20 \mu \mathrm{l} 5 \mathrm{X}$ M-MLV reverse transcriptase buffer, $20 \mu \mathrm{l}$ RNase inhibitor, $60 \mu \mathrm{l}$ RNase-free water), and 3.5 $\mu l$ RNase-free water, and kept at $-80^{\circ} \mathrm{C}$ until reverse transcription (RT) was performed.

After thawing was completed, the content of each tube $(5 \mu \mathrm{l})$ was added to the PCR reaction containing $4 \mu \mathrm{l}$ iScript Reaction Mix (Bio-Rad, Hercules, CA), $1 \mu$ iScript Reverse Transcriptase (Bio-Rad), and $10 \mu \mathrm{l}$ RNase-free water and then was reversely transcribed at $42^{\circ} \mathrm{C}$ for 30 $\min$. The cDNA was then stored at $-80^{\circ} \mathrm{C}$.

There were two rounds of amplification for PCR. The sequences of the primers used in the present study were as follows. $\mathrm{Na}_{\mathrm{v}} 1.7$ (Genbank accession number NM_018852) forward: 5'-GTGGTGTCGCTTGTTGATGG-3', reverse: 5'-CCTTTGCCTGAGATGTGGGT-3', internal: 5'-CCCCAATGGACAGCTTCTTC-3'; RPL19 (Genbank accession number NM_009078, as a control) forward: 5/CTGAAGGTCAAAGGGAATGTGTTC-3', reverse: $5^{\prime}$ TTCGTGCTTCCTTGGTCT-TAGAC-3', internal: $5^{\prime}$ TGCGAGCCTCAGCCTGGTCAGCC- $3^{\prime}$. The first round of amplification used forward and reverse primers. The second round of amplification used one of the primers of the first round and a new internal primer. PCR reaction was performed in a $25-\mu \mathrm{l}$ volume containing $12.5 \mu \mathrm{l}$ iQ SYBR Green Supermix (Bio-Rad), $200 \mathrm{nM}$ (in the first round) or $300 \mathrm{nM}$ (in the second round) of each primer. In the first round of amplification, a $1 \mu \mathrm{l}$ aliquot of the RT product was used and then $2.5 \mu \mathrm{l}$ of the first-round product was used in the second round of amplification. Negative control samples were taken from the aspiration buffer without cells. The cDNA was amplified by real-time quantitative PCR with an ABI StepOnePlus Real-Time PCR System (Applied Biosystems, Foster City, CA). After $10 \mathrm{~min}$ of denaturation at $94^{\circ} \mathrm{C}$, the amplification was performed with 20 (in the first round) or 40 (in the second round) thermal cycles of $94^{\circ} \mathrm{C}$ for $1 \mathrm{~min}, 56^{\circ} \mathrm{C}$ for $2 \mathrm{~min}$, $72^{\circ} \mathrm{C}$ for $2 \mathrm{~min}$, and a final extension at $72^{\circ} \mathrm{C}$ for $5 \mathrm{~min}$. For quantification, $\mathrm{Na}_{\mathrm{v}} 1.7$ gene was normalized to the expressed housekeeping gene RPL19. The data were analyzed by the $2^{-\Delta \Delta \mathrm{Ct}}$ method [40].

\section{Data analysis}

All data are presented as means \pm SEM. SigmaStat 3.5 was used for data analysis. A one-way ANOVA, with a Bonferroni procedure for post hoc was used in comparisons of cell membrane properties, $\mathrm{Na}^{+}$currents, and mRNA and protein of $\mathrm{Na}_{\mathrm{v}}$ 1.7. All data were confirmed by the Kolmogorov-Smirnov test to fit reasonably within normal distribution and equal variance was confirmed by the Levene test. Statistical significance was accepted when $P<0.05$.

\section{Abbreviations}

DMEM: Dulbecco's modified Eagle's medium; dibutyryl cyclic AMP: N6, 2 '-Odibutyryladenosine $3^{\prime}, 5^{\prime}$-cyclic monophosphate; SDS: Sodium dodecyl sulfate; PVDF: Polyvinylidene fluoride; TEA: Tetraethylammonium; 4-AP: 4aminopyridine; TTX: Tetrodotoxin.

\section{Competing interests}

The authors declare that they have no competing interests.

\section{Authors' contributions}

YLL was principal investigator of the study. $J L$ and $Y L L$ designed the research protocol. JL, HT, DZ, and $H Z$ performed experiments. JL, $H T, D Z, H Z$, and $Y L L$ analyzed and interpreted results of experiments. $J L$ and $Y L L$ drafted and edited manuscript. All authors read and approved final version of manuscript.

\section{Acknowledgements}

This study was supported by National Institute of Health Grant HL-098503 (Y.L. Li).

Received: 22 August 2012 Accepted: 23 October 2012

Published: 25 October 2012

\section{References}

1. Hamprecht B: Structural, electrophysiological, biochemical, and pharmacological properties of neuroblastoma-glioma cell hybrids in cell culture. Int Rev Cytol 1977, 49:99-170.

2. Daniels MP, Hamprecht B: The ultrastructure of neuroblastoma glioma somatic cell hybrids. Expression of neuronal characteristics stimulated by dibutyryl adenosine 3',5' cyclic monophosphate. J Cell Biol 1974, 63:691-699.

3. Dolezal V, Castell X, Tomasi M, Diebler MF: Stimuli that induce a cholinergic neuronal phenotype of NG108-15 cells upregulate ChAT and VAChT mRNAs but fail to increase VAChT protein. Brain Res Bull 2001, 54:363-373.

4. McGee R, Simpson P, Christian C, Mata M, Nelson P, Nirenberg M: Regulation of acetylcholine release from neuroblastoma $\mathrm{x}$ glioma hybrid cells. Proc Natl Acad Sci USA 1978, 75:1314-1318.

5. Bodewei R, Hering S, Schubert B, Wollenberger A: Sodium and calcium currents in neuroblastoma $x$ glioma hybrid cells before and after morphological differentiation by dibutyryl cyclic AMP. Gen Physiol Biophys 1985, 4:113-127.

6. Freedman SB, Dawson G, Villereal ML, Miller RJ: Identification and characterization of voltage-sensitive calcium channels in neuronal clonal cell lines. J Neurosci 1984, 4:1453-1467.

7. Higashida H, Hoshi N, Knijnik R, Zadina JE, Kastin AJ: Endomorphins inhibit high-threshold Ca2+ channel currents in rodent NG108-15 cells overexpressing mu-opioid receptors. J Physiol 1998, 507:71-75.

8. Jin W, Lee NM, Loh HH, Thayer SA: Opioid-induced inhibition of voltagegated calcium channels parallels expression of omega-conotoxinsensitive channel subtype during differentiation of NG108-15 cells. Brain Res 1993, 607:17-22.

9. Kawaguchi A, Asano H, Matsushima K, Wada T, Yoshida S, Ichida S: Enhancement of sodium current in NG108-15 cells during neural differentiation is mainly due to an increase in NaV1.7 expression. Neurochem Res 2007, 32:1469-1475.

10. Liu J, Tu H, Zhang D, Li YL: Changes of calcium channel mRNA, protein and current in NG108-15 cells after cell differentiation. Biochem Biophys Res Commun 2012, 423:55-59.

11. Tsai TY, Wu SN, Liu YC, Wu AZ, Tsai YC: Inhibitory action of L-type Ca2+ current by paeoniflorin, a major constituent of peony root, in NG108-15 neuronal cells. Eur J Pharmacol 2005, 523:16-24.

12. Tsai TY, Tsai YC, Wu SN, Liu YC: Tramadol-induced blockade of delayed rectifier potassium current in NG108-15 neuronal cells. Eur J Pain 2006, 10:597-601. 
13. Acuna-Goycolea C, Brenowitz SD, Regehr WG: Active dendritic conductances dynamically regulate GABA release from thalamic interneurons. Neuron 2008, 57:420-431.

14. Casale AE, McCormick DA: Active action potential propagation but not initiation in thalamic interneuron dendrites. J Neurosci 2011, 31:18289-18302.

15. Catterall WA, Goldin AL, Waxman SG: International Union of Pharmacology. XLVII. Nomenclature and structure-function relationships of voltage-gated sodium channels. Pharmacol Rev 2005, 57:397-409.

16. Lee $\mathrm{RH}$, Heckman $\mathrm{CJ}$ : Essential role of a fast persistent inward current in action potential initiation and control of rhythmic firing. $J$ Neurophysiol 2001, 85:472-475.

17. Chevalier M, Gilbert G, Lory P, Marthan R, Quignard JF, Savineau JP: Dehydroepiandrosterone (DHEA) inhibits voltage-gated T-type calcium channels. Biochem Pharmacol 2012, 83:1530-1539.

18. Gong CL, Wong KL, Cheng KS, Kuo CS, Chao CC, Tsai MF, et al: Inhibitory effects of magnolol on voltage-gated $\mathrm{Na}+$ and $\mathrm{K}+$ channels of NG108-15 cells. Eur J Pharmacol 2012, 682:73-78.

19. Kasai $H$, Neher E: Dihydropyridine-sensitive and omega-conotoxinsensitive calcium channels in a mammalian neuroblastoma-glioma cell line. J Physiol 1992, 448:161-188.

20. Toselli M, Biella G, Taglietti V, Cazzaniga E, Parenti M: Caveolin-1 expression and membrane cholesterol content modulate $\mathrm{N}$-type calcium channel activity in NG108-15 cells. Biophys J 2005, 89:2443-2457.

21. Doebler JA: Effects of protonophores on membrane electrical characteristics in NG108-15 cells. Neurochem Res 2000, 25:263-268.

22. Kowtha VC, Bryant HJ, Krauthamer V, Iwasa KH, Stenger DA: Spontaneous firing of NG108-15 cells induced by transient exposure to ammonium chloride. Cell Mol Neurobiol 1996, 16:1-9.

23. Ma W, Pancrazio JJ, Coulombe M, Dumm J, Sathanoori R, Barker JL, et al: Neuronal and glial epitopes and transmitter-synthesizing enzymes appear in parallel with membrane excitability during neuroblastoma $\mathrm{x}$ glioma hybrid differentiation. Brain Res Dev Brain Res 1998, 106:155-163.

24. Kole MH, Ilschner SU, Kampa BM, Williams SR, Ruben PC, Stuart GJ: Action potential generation requires a high sodium channel density in the axon initial segment. Nat Neurosci 2008, 11:178-186.

25. Akiyama T, Yamazaki T: Adrenergic inhibition of endogenous acetylcholine release on postganglionic cardiac vagal nerve terminals. Cardiovasc Res 2000, 46:531-538.

26. Mulkey RM, Zucker RS: Action potentials must admit calcium to evoke transmitter release. Nature 1991, 350:153-155.

27. Zucker RS: Calcium and transmitter release. J Physiol Paris 1993, 87:25-36.

28. Borst JG, Sakmann B: Calcium influx and transmitter release in a fast CNS synapse. Nature 1996, 383:431-434

29. Weber AM, Wong FK, Tufford AR, Schlichter LC, Matveev V, Stanley EF: $\mathrm{N}$-type $\mathrm{Ca} 2+$ channels carry the largest current: implications for nanodomains and transmitter release. Nat Neurosci 2010, 13:1348-1350.

30. Augustine GJ: How does calcium trigger neurotransmitter release? Curr Opin Neurobiol 2001, 11:320-326.

31. Schneggenburger $R$, Neher $E$ : Intracellular calcium dependence of transmitter release rates at a fast central synapse. Nature 2000, 406:889-893.

32. Zucker RS, Lando L: Mechanism of transmitter release: voltage hypothesis and calcium hypothesis. Science 1986, 231:574-579.

33. Zucker RS, Lando L, Fogelson A: Can presynaptic depolarization release transmitter without calcium influx? J Physiol Paris 1986, 81:237-245.

34. Zucker RS, Haydon PG: Membrane potential has no direct role in evoking neurotransmitter release. Nature 1988, 335:360-362.

35. Crill WE: Persistent sodium current in mammalian central neurons. Annu Rev Physiol 1996, 58:349-362.

36. Kiss T: Persistent Na-channels: origin and function. A review. Acta Biol Hung 2008, 59:1-12.

37. Wu SN, Chen BS, Hsu TI, Peng H, Wu YH, Lo YC: Analytical studies of rapidly inactivating and noninactivating sodium currents in differentiated NG108-15 neuronal cells. J Theor Biol 2009, 259:828-836.

38. Tu H, Zhang L, Tran TP, Muelleman RL, Li YL: Reduced expression and activation of voltage-gated sodium channels contributes to blunted baroreflex sensitivity in heart failure rats. J Neurosci Res 2010, 88:3337-3349.
39. Liu J, Tu H, Zheng H, Zhang L, Tran TP, Muelleman RL, et al: Alterations of calcium channels and cell excitability in intracardiac ganglion neurons from type 2 diabetic rats. Am J Physiol Cell Physiol 2012, 302:C1119-C1127.

40. Livak KJ, Schmittgen TD: Analysis of relative gene expression data using real-time quantitative PCR and the 2(-Delta Delta $C(T)$ ) Method. Methods 2001, 25:402-408.

doi:10.1186/1471-2202-13-129

Cite this article as: Liu et al:: Voltage-gated sodium channel expression and action potential generation in differentiated NG108-15 cells. BMC Neuroscience 2012 13:129.

\section{Submit your next manuscript to BioMed Central and take full advantage of:}

- Convenient online submission

- Thorough peer review

- No space constraints or color figure charges

- Immediate publication on acceptance

- Inclusion in PubMed, CAS, Scopus and Google Scholar

- Research which is freely available for redistribution 